\title{
Study on pattern of gynaecological malignancies at Saveetha Medical College and Hospital, Tamil Nadu, India
}

\author{
Shanthi Ethirajan, Mohanapriya D.*, Aarthi C.
}

Department of Obstetrics and Gynecology, Saveetha Medical College, Thandalam, Tamil Nadu, India

Received: 10 June 2018

Accepted: 03 July 2018

\section{*Correspondence:}

Dr. Mohanapriya D.,

E-mail: priya_medico87@yahoo.co.in

Copyright: () the author(s), publisher and licensee Medip Academy. This is an open-access article distributed under the terms of the Creative Commons Attribution Non-Commercial License, which permits unrestricted non-commercial use, distribution, and reproduction in any medium, provided the original work is properly cited.

\begin{abstract}
Background: The burden of malignancy and deaths due to it are rising worldwide. In women gynaecological malignancies are among the most common cancers. This study was undertaken to study the pattern and relative frequencies of gynaecological malignancies among women admitted in the Department of Gynaecology, at Saveetha Medical College and Hospital, Tamil Nadu.

Methods: This is a retrospective observational study done at the department of Saveetha Medical College and Hospital over a period of two years from September 2015 to September 2017. Case records of women admitted in the Department of Gynaecology and diagnosed to have gynaecological malignancy were retrieved from the department of medical records. Information regarding demographic details, site of malignancy, histopathology of malignancy was analysed and expressed as percentages.

Results: During the study period 49 cases of gynaecological malignancies were reported. Out of 49 cases, 36 cases were cancer cervix, followed by 7 cases of ovarian malignancy and 6 cases of cancer of uterine corpus. The mean ages of cancer cervix, ovary and corpus uteri were 51.1, 53.3 and 47.2 years respectively. All women were multiparous in the study. One third of women were premenopausal. Women with cancer cervix and corpus uteri commonly presented with irregular bleeding, post-menopausal bleeding and white discharge per vaginum. Ovarian cancers presented commonly with abdominal pain and distension. Squamous cell carcinoma of cervix was the commonest histopathology seen. Adenocarcinoma and epithelial cancer was the commonest histopathology seen in endometrial and ovarian cancer respectively.

Conclusions: Cancer cervix was the commonest gynaecological malignancy in the study population followed by ovarian and uterine malignancies.
\end{abstract}

Keywords: Cervical cancer, Cancer corpus uteri, Frequency of gynaecological malignancy, Ovarian cancer

\section{INTRODUCTION}

Cancer is the major cause of mortality and morbidity in the world. The incidence and deaths due to cancers are on the rise globally. Malignancy places tremendous strain on not only the patients, but also the families and society. Cancer forms an important health problem worldwide. Gynaecological cancers are among the most common cancers in women. ${ }^{1}$ Their distribution and frequencies vary from one country to another. In developed countries cancer endometrium is the commonest gynaecological malignancy, where as in developing countries, it is the cervical cancer that ranks first in incidence. ${ }^{2-5}$ Differences in the mortality rates also exist across the world. Difference in the distribution of malignancies and mortality rates may be due to the difference in life style, food habits, education, awareness, health care system, screening programs etc. ${ }^{6}$ In developed countries, well 
organised screening program, surveillance, and regular follow up exist. And more over, people are well educated with knowledge about cancers and screening program and the importance to undergo regular screening. Hence people are detected in the premalignant condition or at an early stage of malignancy and therefore incidence and mortality due to cervical cancers are less in developed countries.

Lack of reliable screening methods change in the life style and diet pattern may be responsible for the increasing ovarian and endometrial cancers. Increasing diabetes, obesity, sedentary life style, early menarche and late menopause may be some of the reasons for the rising incidence of endometrial cancers. ${ }^{7}$ Mortality due to endometrial cancer is less as the stage at presentation is early which is amenable to treatment. ${ }^{8}$ Mortality due to ovarian cancers is high, as the symptoms of ovarian malignancy are nonspecific, and the stage is advanced, by the time women presents to the clinician. ${ }^{8}$

Age and parity affect incidence of gynaecological malignancies. Endometrial and ovarian cancers are more common in older age group while cervical cancer is more common in pre and peri menopausal age group. ${ }^{2,4}$ Parity protects from endometrial and ovarian cancer whereas cancer cervix is more common among multiparous women. ${ }^{2,4}$ Vulval and vaginal cancers are relatively rare.

As the frequency and distribution of gynaecological malignancies vary from region to region, this study aims at determining the pattern of malignancies in our population and help us to identify the burden of these cancers in our population.

\section{METHODS}

This is a retrospective observational study done at Gynaecological Department of Saveetha Medical College and Hospital. Study population included all women admitted in gynaecology department between 2015 September and 2017 September. Among them all cases diagnosed of gynaecological malignancies were included in the study group.

Gynaecological malignancies include malignancy of vulva, vagina, cervix, uterine, fallopian tube and ovarian malignancies. Cases with benign tumours were excluded from the study. The case records of these cases were retrieved from the department of medical records. From that, the information collected were demographic, clinical, investigational, treatment (medical/ surgical) and histo-pathological data using pro-forma. The demographic and general details included, age, residence, marital status, parity, sterilization. Information related to the disease like symptoms, the site and stage of the tumour, histopathology and treatment given were collected. The data collected were analysed for determining the relative frequencies of the tumours.
Data were analyzed using Microsoft excel and include descriptive statistics for demographic data and expressed in percentage.

\section{RESULTS}

A total of 49 cases of gynaecological malignancies were reported during the study period of two years, in the Department of Gynaecology at Saveetha Medical College and Hospital. The relative frequency distributions of various gynaecological malignancies are tabulated. The most commonly occurring cancer was cervical cancer (36 cases).

This was followed by the ovarian cancer ( 7 cases) and then cancer corpus uteri ( 6 cases). Among the six cases of cancer from the body of the uterus, three were endometrial cancers and two were mixed Mullerian tumour. No vaginal, vulval or fallopian tube cancers were seen in the study population during the study period (Table 1).

\section{Table 1: Site distribution of gynaecological} malignancies.

\begin{tabular}{|c|c|c|}
\hline Site of malignancy & No. of cases & Total cases \\
\hline \multicolumn{3}{|l|}{ Cancer cervix } \\
\hline Invasive & 34 & \multirow[t]{2}{*}{36} \\
\hline In situ & 2 & \\
\hline \multicolumn{2}{|c|}{ Cancer of corpus uterus } & \multirow{3}{*}{6} \\
\hline Endometrium & 4 & \\
\hline Others & 2 & \\
\hline \multirow[t]{2}{*}{ Ovary } & 7 & 7 \\
\hline & Total & 49 \\
\hline
\end{tabular}

Age of cancer cervix cases ranged from 37 years to 74 years. Ovarian cancer occurred in women between 29 years and 66 years. Cases of carcinoma endometrium were between 41 to 55 years of age.

The ages of two cases with Carcino-sarcoma were 50 and 70 years. The mean ages of cancer cervix, ovarian and corpus uteri were $51.1,53.3$ and 47.2 years respectively (Table 2).

\section{Table 2: Age distribution of gynaecological} malignancies.

\begin{tabular}{|llll|}
\hline $\begin{array}{l}\text { Age } \\
\text { (years) }\end{array}$ & $\begin{array}{l}\text { Site of malignancy, No. of cases } \\
\text { Cervix }\end{array}$ & Body of uterus & Ovary \\
\hline $20-29$ & - & - & 1 \\
\hline $30-39$ & 4 & 2 & - \\
\hline $40-49$ & 14 & 3 & 4 \\
\hline $50-59$ & 10 & - & 1 \\
\hline $60-69$ & 7 & - & 1 \\
\hline $70-79$ & 1 & 1 & - \\
\hline
\end{tabular}

All women with genital malignancies were parous in the present study (Table 3). Abnormal bleeding per vaginum 
was the most common presenting complaint followed by white discharge per vaginum in women with cancer cervix and corpus uteri. Women with ovarian cancer had pain abdomen and abdominal distension as a frequent presenting symptom. Woman with carcinoma insitu presented with white discharge per vaginum. Some women presented with more than one complaint (Table 4).

Table 3: Parity distribution of gynaecological malignancies.

\begin{tabular}{|l|lll|}
\hline Parity & \multicolumn{2}{l}{ Site of malignancy } & \\
\hline Nulliparous & - & - & Ovary \\
\hline $1-2$ & 6 & 2 & - \\
\hline $3-4$ & 21 & 1 & 1 \\
\hline 5 and above & 8 & 1 & 6 \\
\hline
\end{tabular}

Table 4: Pattern of clinical presentation of gynaecological malignancies.

\begin{tabular}{|llll|}
\hline $\begin{array}{l}\text { Presenting } \\
\text { complaint }\end{array}$ & $\begin{array}{l}\text { Site of malignancy } \\
\text { Cervix }\end{array}$ & Body of uterus & Ovary \\
\hline $\begin{array}{l}\text { White discharge } \\
\text { per vaginum }\end{array}$ & 8 & 4 & - \\
\hline Menorrhagia & 7 & - & - \\
\hline Metorrhagia & 2 & - & - \\
\hline $\begin{array}{l}\text { Post-menopausal } \\
\text { bleeding }\end{array}$ & 7 & 3 & 1 \\
\hline $\begin{array}{l}\text { Abdominal } \\
\text { pain }\end{array}$ & 6 & - & 4 \\
\hline $\begin{array}{l}\text { Abdominal } \\
\text { distension }\end{array}$ & - & - & 4 \\
\hline
\end{tabular}

Table 5: Menopausal status of women with gynaecological malignancies.

\begin{tabular}{|lllll|}
\hline $\begin{array}{l}\text { Menopausal } \\
\text { status }\end{array}$ & Servix & $\begin{array}{l}\text { Site of malignancy } \\
\text { Body of } \\
\text { uterus }\end{array}$ & Ovary & $\begin{array}{l}\text { Total } \\
\text { (no. of } \\
\text { cases) }\end{array}$ \\
\hline $\begin{array}{l}\text { Pre- } \\
\text { menopausal }\end{array}$ & 15 & 1 & 3 & 19 \\
\hline $\begin{array}{l}\text { Post- } \\
\text { menopausal }\end{array}$ & 21 & 5 & 4 & 30 \\
\hline
\end{tabular}

Among 49 women with genital cancer 19 women were premenopausal and 30 women were postmenopausal. 15 women with cervical cancer were premenopausal and 21 were postmenopausal.

One woman was premenopausal, and five women were post-menopausal among women with uterine cancer. Among women with ovarian cancer, three were premenopausal and four were postmenopausal (Table 5).

Table 6: Histological types of gynaecological malignancies.

\begin{tabular}{|lll|}
\hline \multirow{3}{*}{$\begin{array}{l}\text { Site of } \\
\text { malignancy }\end{array}$} & $\begin{array}{l}\text { Histological type } \\
\text { Cervix }\end{array}$ & $\begin{array}{l}\text { Frequency } \\
\text { (No. of } \\
\text { cases) }\end{array}$ \\
\cline { 2 - 3 } Corpus uteri & Squamous cell carcinoma & 29 \\
\cline { 2 - 3 } & Adenocarcinoma & 6 \\
\cline { 2 - 3 } & Adeno squamous & 1 \\
\cline { 2 - 3 } & adenocarcinoma & 3 \\
\cline { 2 - 3 } Ovary & Mixed Mullerian Tumour & 2 \\
\cline { 2 - 3 } & $\begin{array}{l}\text { Clear cell } \\
\text { Mixed malignant germ }\end{array}$ & 1 \\
\cline { 2 - 3 } & cell tumour & 1 \\
\cline { 2 - 3 } & $\begin{array}{l}\text { Mucinous cystadeno } \\
\text { carcinoma }\end{array}$ & 3 \\
\cline { 2 - 3 } & Serous carcinoma & 2 \\
\cline { 2 - 3 } & Metastatic carcinoma & 1 \\
\hline
\end{tabular}

Squamous cell carcinoma of cervix was the commonest histopathology seen. Adenocarcinoma and epithelial cancer was the commonest histopathology seen in endometrial and ovarian cancer respectively (Table 6).

\section{DISCUSSION}

Cancers are one of the common causes for the morbidity and mortality. In this study cancer cervix $(73.4 \%)$ was the commonest genital cancers among women. The results are similar to that of other Indian studies and few other countries. Jeph V et al from Haryana reported $67.2 \%$ and Agarwal et al reported $71.47 \%$ from Delhi in their studies. ${ }^{9,10}$ Jhansivani $Y$ et al from Guntur reported $85 \%$ of cancer cervix in their studies. ${ }^{11}$ Joseph A et al reported $60.6 \%$ in Nigeria. $^{4}$ Contrary to this was reported from Pakistan, where ovarian cancer $(72.5 \%)$ was the leading gynecological cancer. ${ }^{3,6}$

In European countries endometrial cancers were the commonest female genital cancers. ${ }^{12,13}$ The second commonest cancer in our study was the ovarian malignancy followed by the corpus uteri cancer. This is similar to other studies from other parts of India and Nigeria. ${ }^{9,10,14}$ The differences in the patterns of frequency of gynaecological malignancy could be due to the differences in availability of screening programs, education, awareness, lifestyle, diet etc.

The median age of cancer cervix, ovary, and corpus uteri was 50, 48 and 48.5 years respectively, which is comparable with studies done by Agarwal et al. ${ }^{10}$ But according to SEER registry, the median age of occurrence of cervical cancer was lower (48 years) whereas ovarian and uterine cancers occurred at an older age group..$^{6,12}$

The mean age of women with insitu cancer cervix was 44 years. This correlates with the fact that premalignant changes begin early in the reproductive age group and has a long lead time before it becomes malignant. Hence by screening all women in reproductive age group, premalignant lesions can be detected, and its treatment can 
prevent progression to cancer cervix, thereby reducing the incidence, morbidity and mortality of cancer cervix.

All women with genital cancers were parous in present study, none were nulliparous. Cancer cervix was common among women with high parity (3-4)., ${ }^{2,7}$ But Nigerian studies showed that cancer cervix occurred at a higher order parity ( 5 and above). This may be due to higher order parity occurring at Nigeria when compared to our population where people are aware of the use of family planning methods. ${ }^{7}$

Both ovarian and uterine cancer also commonly occurred in parous women in the present study, in contrary to the fact that parity gives protection to these cancers. This is similar to study results from Ghana. ${ }^{2}$

Generally, cancers are considered to be a disease of old age, but more than one third were premenopausal in the study population. Menstrual complaints were one of the common symptoms of genital malignancies. The clinical presentation of cancer cervix and corpus uteri was irregular bleeding, post-menopausal bleeding and white discharge per vaginum. Ovarian cancers presented commonly with abdominal pain and distension. These findings are consistent with other studies. ${ }^{8,15}$

Squamous cell carcinoma of the cervix was the most common histological type seen in this study group. Epithelial cancer of the ovary was the commonest histological type, though germ cell tumours and metastatic tumours were also reported. The commonest histological type of endometrial cancer was adenocarcinoma. These results are similar to other studies. ${ }^{11,16}$

\section{CONCLUSION}

According to this study, cancer cervix is the commonest gynaecological malignancy in this population followed by ovarian and corpus uterine malignancies. Though cancer cervix is a preventable and easily accessible cancer, the incidence is still high.

By strengthening the health programs including regular Pap smear screening, public awareness campaigns, HPV vaccination and follow up surveillance, prevention, early diagnosis and treatment of cancer cervix is possible. In low resource settings visual inspection with acetic acid (VIA) and visual inspection with Lugol's iodine (VILI) will help in down staging cancer cervix.

Reliable screening method for endometrial and ovarian cancers is the need of the hour to reduce the incidence of these cancers. Along with that provision of accessible and affordable health care to lower socio economic group is essential. This in turn would reduce the morbidity and mortality due to gynaecological cancers.

Funding: No funding sources
Conflict of interest: None declared

Ethical approval: The study was approved by the Institutional Ethics Committee

\section{REFERENCES}

1. Maheshwari A, Kumar N, Mahantshetty U. Gynecological cancers: a summary of published Indian data. South Asian J Cancer. 2016;5(3):112-20.

2. Nkyekyer K. Pattern of gynaecological cancers in Ghana. East Afr Med J. 2000;77(10):534-8.

3. Jamal S, Mamoon N, Mushtaq S, Luqman M, Moghal S. The pattern of gynecological malignancies in 968 cases from Pakistan. Ann Saudi Med. 2006;26(5):382-4.

4. Joseph A, Olisaemeka EP, Chukwudi OR, Igwe NM, Rose AM, Conrad EC. Frequency and pattern of gynaecological cancers in federal teaching hospital, Abakaliki, Nigeria. J Basic Clin Reprod Sci. 2015;4(2):54-7.

5. Indian Council of Medical Research. Bangalore: National Cancer Registry Programme 2007. Consolidated Report of Hospital Based Cancer Registries 2001-2003. 2007. Available at www.icmr.nic.in/ncrp/report.

6. Manzoor H, Naheed H, Ahmad K, Iftikhar S, Asif M, shuja J, et al. Pattern of gynaecological malignancies in south western region of Pakistan: An overview of 12 years. Biomed Rep. 2017;7:487-91.

7. Singh A, Kujur AV. Changing trends in genital cancer. Int J Reprod Contracept Obstet Gynecol. 2017;6(3):850-5.

8. Mohyuddin S, Sultana N, Butt KA, Mohyuddin A. Patterns of gynaecological malignancies at a tertiary care hospital. PJMHS. 2012;6(1):47-51.

9. Jeph V, Adreena, Garg PK, Mahabole K. Incidence of different malignancies in female genital tract: study in 504 women in rural population. Int $\mathbf{J}$ Contemp Med Res. 2017;4(1):274-86.

10. Agarwal S, Malhotra KP, Sinha S, Rajaram S. Profile of gynaecologic malignancies reported at a tertiary care centre in India over the past decade: Comparative evaluation with international data. Indian J Cancer. 2012;49(3):298-302.

11. Jhansivani Y, Rani S. Epidemiology of gynecological cancers in a tertiary care center (Government General Hospital, Guntur). IOSR J Dent Med Sci. 2015;14(9):41-5.

12. Seer.cancer.gov [homepage on the internet]. Bethesda, Maryland: North American Association of Central Cancer Registries; c2000. SEER Cancer statistics review 1975-2007. Available from: http:// www.seer.cancer.gov/resources.

13. Boyle P, Ferlay J. Cancer incidence and mortality in Europe. Ann Oncol. 2005;16:481-8.

14. Okeke TC, Onah N, Ikeako LC, Ezenyeaku CCT. The frequency and pattern of female genital tract malignancies at the University of Nigeria Teaching Hospital, Enugu, Nigeria. Ann Med Health Sci Res. 2013;3(3):345-8. 
15. Junejo N, Shaikh F, Mumtaz F. Clinical presentation and treatment outcome of ovarian tumours at gynecology ward. J Liaquat University Med Health Sci. 2010;9(1):30-2.

16. Yakasai IA, Ugwa EA, Otubu J. Gynecological malignancies in Aminu Kano Teaching Hospital
Kano: a 3-year review. Nigerian J Clin Pract. 2013;16(1):63-6.

Cite this article as: Ethirajan S, Mohanapriya D, Aarthi C. Study on pattern of gynaecological malignancies at Saveetha Medical College and Hospital, Tamil Nadu, India. Int J Reprod Contracept Obstet Gynecol 2018;7:3343-7. 